\title{
Pola Penyakit Infeksi pada Thalassemia
}

\author{
Mururul Aisyi, Alan R Tumbelaka
}

\begin{abstract}
Pasien thalassemia rentan terhadap infeksi akibat faktor penyakitnya maupun akibat pengobatan. Kelebihan besi yang terjadi akibat transfusi berulang mempengaruhi sistim imun, menekan aksi kemotaksis fagositosis, mikrobiosidal leukosit mononuklear dan polimorfonuklear. Penularan infeksi melalui transfusi seperti virus hepatitis, HIV dan CMV merupakan komplikasi transfusi yang ditakuti. Infeksi virus hepatitis yang ditularkan melalui transfusi antara lain hepatitis $\mathrm{A}$, Hepatitis $\mathrm{B}$, hepatitis $\mathrm{C}$ dan hepatitis D. hepatitis C mungkin merupakan penyebab utama sirosis hepatitis pada pasien thalassemia yang mendapat transfusi. Infeksi bakteri $S$. pneumoniae merupakan penyebab terbanyak bakteremia terutama pada pasien thalassemia yang menjalani operasi splenektomi. Osteomielitis yang terjadi akibat infeksi tulang yang mengalami infark biasanya disebabkan oleh spesies Salmonella. Vaksin polisakarida pneumokokus direkomendasikan pada anak 2 tahun atau lebih dan ulangan diberikan setelah 3-5 tahun pada pasien thalassemia di bawah umur 10 tahun. Infeksi parasit malaria pada thalassemia sangat rendah; terdapat bukti yang terbatas bahwa perubahan respons imun pada pasien dengan varian gen globin mungkin berperan penting pada resistensi terhadap malaria. Mengingat banyaknya penyakit atau komplikasi yang timbul pada pasien thalassemia maka perlu dilakukan pemantauan seumur hidup.
\end{abstract}

Kata kunci: thalassemia, bakteri, sistim imun

D i Indonesia frekuensi gen thalassemia berkisar antara 3-8\%. Di Sub Bagian Hematologi Anak FKUI/RSCM saat ini tidak kurang dari 700 orang pasien yang berobat di Poliklinik. ${ }^{1}$ Thalassemia dapat menimbulkan masalah medis dari sosial yang hingga saat ini belum dapat diatasi di seluruh dunia. Salah satu aspek penting dalam tata laksana jangka panjang thalassemia adalah terjangkit infeksi. Pada thalassemia, beberapa faktor diduga dapat mengakibatkan kerentanan pasien terhadap infeksi. Baik faktor akibat penyakitnya sendiri maupun akibat

Dr. Mururul Aisyi: PPDS Ilmu Kesehatan Anak FKUI, Jakarta

Alamat Korespondensi:

Dr. Alan R Tumbelaka, Sp.A(K).

Subbagian Infeksi dan Penyakit Tropis, Bagian Ilmu Kesehatan Anak FKUI-RSCM.

Jl. Salemba no. 6 Jakarta 10430.

Telepon. 391 4126. Fax.: 3907743. pengobatan dan tindakan yang dilakukan dalam perjalanan alamiah penyakit thalassemia. Dengan kerentanannya terhadap infeksi, maka sangat penting untuk mengetahui berbagai penyakit infeksi yang dapat dialami seorang pasien thalassemia.

Komplikasi yang mungkin terjadi pada perjalanan penyakit thalassemia adalah hemolisis kronik, kerentanan terhadap infeksi pasca splenektomi, infeksi melalui transfusi darah, perburukan anemia selama infeksi, ikterus, ulkus tungkai, kolelitiasis, fraktur patologis, gangguan pertumbuhan, pubertas terlambat, hepatic siderosis, splenomegali, penyakit jantung karena kelebihan besi, dan krisis aplastik ${ }^{2}$.

\section{Keadaan Imunokompromais pada Tha- lassemia}

Secara umum, mekanisme kontrol terhadap infeksi intraselular seperti infeksi virus, protozoa, jamur, dan 
beberapa bakteri intraselular fakultatif terutama oleh imunitas selular; sedangkan bakteri ekstraselular dan toksin membutuhkan imunitas yang diperankan oleh antibodi. ${ }^{3}$ Berbagai faktor dapat mempengaruhi kerentanan pasien thalassemia terhadap infeksi, baik karena penyakit thalassemia ataupun dampak pengobatan.

Sebagai bagian dari sistem retikuloendotelial, fungsi limpa dapat dibagi menjadi beberapa bagian, yaitu fagositosis dan klirens materi yang tidak teropsonisasi, perkembangan respons imun spesifik dan produksi opsonin. Limpa merupakan lokasi respons imun awal (IgM primer). Pada orang normal, sekuestrasi bakteri selama infeksi akan merangsang sintesis antibodi awal secara cepat. ${ }^{4}$ Setelah splenektomi, kadar imunoglobulin (IgA, IgM, IgG) menurun secara bervariasi. Banyak data menunjukkan penurunan kadar IgM. Terjadi gangguan produksi antibodi terhadap pneumokokus, akan tetapi respons antibodi terhadap antigen yang berasal dan paparan kulit terlihat normal pada kasus thalassemia pasca splenektomi, yang menunjukkan respons antibodi pada limpa terutama penting dalam responsnya terhadap antigen intravaskular. ${ }^{4}$ Suatu studi prospektif untuk menilai fungsi imun pada kasus thalassemia yang mengalami splenektomi memperlihatkan kesan bahwa splenektomi tidak mengubah status imunnya. ${ }^{5}$

Kelebihan besi yang terjadi dapat mempengaruhi sistem imun. Besi yang berlebihan dalam tubuh bukan saja merupakan nutrien esensial untuk pertumbuhan bakteri tetapi juga menekan aksi kemotaksis, fagositosis, mikrobisidal leukosit mononuklear dan polimorfonuklear. ${ }^{6}$ Efek kelebihan besi terhadap sel limfosit $T$ adalah ditemukannya penurunan rasio $\mathrm{CD}_{4}$ : $\mathrm{CD}_{8}$. Pada thalassemia hal ini disebabkan terutama akibat penurunan jumlah sel $\mathrm{CD}_{4}$, walaupun peningkatan jumlah sel $\mathrm{CD}_{8}$ juga dilaporkan. Kemungkinan lain yang dapat menyebabkan keadaan tersebut adalah stimulasi alloantigen kronis karena transfusi darah yang berulang. ${ }^{7}$

\section{Pola Infeksi pada Thalassemia}

Pada anak dengan hemoglobinopati, peningkatan insidens pneumonia, osteomielitis, meningitis, infeksi saluran kemih dan genital akibat S.pneumoniae, H.infuenza type b, Salmonella, Shigella, Edwardsiella tarda dan Mycoplasma terjadi. ${ }^{8}$ Risiko infeksi juga akan meningkat dengan berbagai tindakan pada pengobatan thalassemia seperti transfusi dan splenektomi. Pada transfusi, bakteri dapat masuk ke dalam komponen darah karena a/antisepsis yang tidak efektif, bakteremia asimtomatik pada saat donasi dan containers yang terkontaminasi. ${ }^{9}$ Davis dan Porter melaporkan peningkatan risiko infeksi dan tromboemboli pada pasien thalassemia beta yang mendapat kelasi intravena kontinu. ${ }^{10}$

Sepsis pasca splenektomi karena kelainan hematologi seperti thalassemia, mempunyai insidens paling tinggi (sampai dengan 25\%) dibandingkan dengan splenektomi karena sebab lain. ${ }^{4}$ Komplikasi juga dapat ditimbulkan pada pemberian kelasi perkutan jangka panjang, yang akan meningkatkan risiko infeksi. ${ }^{11}$

\section{Infeksi Virus}

Sebagai tindak lanjut pada pasien thalassemia pasca transfusi sangat penting. Beberapa laporan memperlihatkan kelebihan besi, hepatitis kronik, fungsi jantung, dan defisiensi endokrin dapat lebih mudah ditatalaksana setelah transplantasi. Oleh karena itu dianjurkan untuk melakukan transplantasi sumsum tulang pada tahap awal penyakit, sebelum terjadi penyulit dan kerusakan organ (terutama jantung dan hati). ${ }^{12}$

Komplikasi penularan infeksi melalui transfusi adalah salah satu komplikasi transfusi yang paling ditakuti. Perbaikan yang bermakna didapat melalui skrining darah donor dan uji laboratorium. ${ }^{13}$ Transfusi dapat menularkan infeksi (blood borne infection) termasuk virus hepatitis, HIV (buman immunodeficiency virus) dan $C M V$ yang menggambarkan insidens pada populasi umum. Pada daerah endemik hepatitis $\mathrm{C}, 90 \%$ pasien yang mendapat transfusi kronik akan mengalami hepatitis $\mathrm{C}$ dalam waktu 5 tahun. Delapan puluh lima persen kasus yang menderita infeksi kronis, pada akhirnya akan menyebabkan sirosis. Pasien harus dipantau peningkatan kadar transaminase dan antibodi hepatitis C dan harus diimunisasi hepatitis A dan B. ${ }^{14}$

Infeksi virus hepatitis yang ditularkan melalui transfusi secara umum antara lain hepatitis A (jarang), hepatitis B (1:63.000-1:233.000), hepatitis C (1:120.000), dan hepatitis D jarang. ${ }^{13}$ Transmisi virus hepatitis $\mathrm{C}$ dilaporkan meningkat pada anak yang mendapat multitransfusi seperti pada thalassemia. Angka prevalens antibodi anti HCV ditemukan sekitar 40-95\% pada pasien tersebut ${ }^{15,16}$ Prevalens antibodi $\mathrm{HCV}$ berhubungan langsung dengan jumlah transfusi 
darah . Suatu studi kohort prospektif yang dilakukan Pratti dkk, selama 3 tahun melaporkan disfungsi hati masih sering terjadi pada pasien thalassemia, terutama akibat siderosis dan infeksi $\mathrm{HCV}$ primer. ${ }^{17}$

Laporan lain menyebutkan prevalens HCV pada anak dengan thalassemia sebesar 60\%, hemofilia $98 \%$ dan yang mengalami hemodialisa sebesar $15-29 \% .{ }^{18}$ Sebelum diperkenalkannya skrining darah donor terhadap hepatitis $\mathrm{C}$, banyak pasien thalassemia yang datang untuk transplantasi telah terinfeksi $\mathrm{HCV} .{ }^{19}$ Skrining darah donor untuk antibodi HCV akan menurunkan insidens infeksi HCV pada pasien thalassemia tersebut.

Hepatitis $\mathrm{C}$ mungkin merupakan penyebab utama sirosis hepatis pada pasien thalassemia yang mendapat transfusi. ${ }^{20}$ Petanda serologis infeksi $\mathrm{HCV}$ positif pada 40 $80 \%$ anak thalassemia dengan multitransfusi. Pada satu studi prospektif selama 8 tahun, 83 diantara 153 pasien baru terdiagnosis thalassemia menderita NANBH, dan anti HCV terdeteksi pada 75 diantara 83 anak (90\%) dan menjadi kronik pada hampir $80 \%$ yang didasarkan pada adanya peningkatan aminotransferase persisten. Dengan menggunakan analisis berturutan ditunjukkan bahwa HCV tidak merangsang imunitas protektif pada pasien yang terinfeksi secara kronik. Studi prospektif lain selama 4 tahun pada 61 pasien, mendapatkan bahwa anak dengan infeksi HCV memiliki kadar aminotransferase yang lebih tinggi dibandingkan dengan yang lain. Bahkan, fibrosis hepar seringkali terjadi pada pasien dengan infeksi $\mathrm{HCV}^{21}$

Tidak terdapat bukti untuk transmisi seksual HEV (virus hepatitis E) atau dengan transfusi darah atau produk darah. Antibodi anti HEV pada pasien thalassemia, hemofilia dan pasien yang memakai obat intravena sama dengan populasi secara umum. ${ }^{22}$

Suatu studi di Italia menunjukkan infeksi secara luas virus Hepatitis C pada pasien-pasien thalassemia. ${ }^{23}$

Satu virus baru yang dihubungkan dengan hepatitis pasca transfusi diidentifikasi pada tahun 1997 pada tiga pasien di Jepang yang mengalami peningkatan konsentrasi aminotransferase pasca transfusi dan memiliki hasil tes negatif terhadap semua virus hepatitis yang diketahui. Virus yang saat ini dikenal dengan nama TTV (tranfusion transmitted virus) mempunyai sifat hepatotropisme dan titernya berhubungan dengan peningkatan konsentrasi aminotransferase menunjukkan bahwa virus tersebut adalah true hepatitis virus. Data yang didapat menunjukkan kemampuan TTV menyebabkan infeksi kronik. Walaupun demikian hubungan antara infeksi TTV dan hepatitis akut/ kronik belum diamati secara konsisten. Delapan puluh empat persen pasien thalassemia yang ditransfusi di Italia dilaporkan mendapat infeksi TTV. ${ }^{24}$

Infeksi TTV sering ditemukan dan menetap pada pasien yang tergantung transfusi. Oleh karena viremia yang tinggi didapatkan pada donor sehat, maka diambil kesimpulan bahwa bukan hanya jalur parenteral yang merupakan cara penyebaran TTV. ${ }^{2}$

Human parvovirus B19 merupakan virus DNA yang mempunyai manifestasi mayor krisis aplastik, eritema infeksiosa, hidrops fetalis, rheumatoid-like arthropathy pejamu imunokompromais, supresi sumsum tulang kronik atau berulang. ${ }^{26}$ Pada anak, parvovirus B19 menyebabkan eksantem yang dikenal dengan fifth disease. Pada beberapa pasien thalassemia, virus ini dapat menyebabkan anemia aplastik/hipoplastik akut. Pemberian infus imunoglobulin memperbaiki aplasia pada beberapa pasien. ${ }^{13}$ Krisis aplastik akibat infeksi parvovirus B19 pernah dilaporkan pada kasus thalassemia. Krisis aplatik ini ditandai dengan anemia berat, penurunan retikulositosis, dan hilangnya prekursor eritroid dalam sumsum tulang. ${ }^{26-28}$

Infeksi HIV pasca transfusi terjadi sebelum adanya uji antibodi HIV pada tahun 1985. Saat ini diketahui terdapat window period antara infeksi HIV dan terdeteksinya antibodi HIV-1, HIV-2, atau uji Ag HIV1 p24 adalah 16 hari. Risiko terjadinya infeksi HIV adalah 1:676.000. ${ }^{13}$

HTLV I yang dihubungkan dengan leukemia sel T/limfoma pada orang dewasa sedangkan HTLV-II dihubungkan dengan peningkatan risiko infeksi bakteri, mikobakteri dan jamur dapat disebarkan lewat transfusi. Virus HIV ini berada pada leukosit intraselular sehingga penyebarannya berhubungan dengan komponen selular (transmisi tidak dapat terjadi pada transfusi plasma atau kriopresipitat). Interval antara paparan dan deteksi antibodi sekitar 51 hari. Risiko penularan per unitnya adalah $1: 640.000 .^{13}$

CMV (Cytomegalovirus) terdapat dalam leukosit polimorfonuklear dan limfosit, jarang menyebabkan gejala pada pasien imunokompeten. Sebaliknya pasien dengan seronegatif CMV yang menerima transplantasi sumsum tulang dan donor yang seronegatif CMV dan bayi dengan berat kurang dan $1200 \mathrm{~g}$ yang lahir dari ibu seronegatif mendapat morbiditas dan mortalitas yang bermakna jika mereka mendapat infeksi CMV melalui transfusi. Transmisi dapat diturunkan dengan 
menyeleksi komponen darah atau dengan membuang leukosit melalui filtrasi. ${ }^{13}$

\section{Infeksi Bakteri}

Komplikasi infeksi merupakan penyebab utama morbiditas dan mortalitas pada thalassemia. S.pneumoniae, penyebab terbanyak bakteremia pada anak dengan sickle cell disease, dapat disertai dengan krisis aplastik, disseminated intravascular coagulation (DIC) dan mempunyai angka kematian 20-50\%. Penyebab kematian kedua adalah bakteremia. Infeksi Haemophilus Influenzae type $b$ mengenai anak yang lebih besar, bersifat lebih ringan, tetapi kadangkadang dapat juga fatal. ${ }^{29}$

Pneumonia bakterialis merupakan salah satu penyebab acute chest syndrome. Maka pasien dengan gejala dispne, batuk, nyeri dada, demam, takipne dan leukositosis harus dievaluasi dengan foto dada, pemeriksaan analisis gas darah, kultur darah dan sputum serta pemeriksaan serologis terhadap Mycoplasma pneumoniae, Chlamydia pneumoniae, dan Legionella species. Mycoplasma pneumoniae dan Chlamydia pneumoniae berperan dalam 29\% kasus acute chest syndrome. Sedangkan S. pneumoniae dan $H$. influenzae type $b$ merupakan penyebab yang lebih jarang. ${ }^{29}$

Osteomielitis dapat terjadi pada thalassemia, kemungkinan akibat infeksi pada tulang yang mengalami infark. Osteomielitis biasanya disebabkan Spesies Salmonella $S$. aureus berperan pada kurang dari $25 \%$ kasus, sering bersifat multipel pada tulang panjang. Diagnosis dibuat berdasarkan kultur darah atau tulang yang terinfeksi. Infeksi sendi lebih jarang dan sering disebabkan S. pneumoniae. ${ }^{29}$

Pada thalassemia pasca splenektomi dapat terjadi episode sepsis berulang. Kemungkinan penyebab episode sepsis berulang adalah fungsi limpa yang sangat berkurang, defisiensi spesifik yang tidak diketahui dalam fungsi imun, dan kolonisasi pneumokokus pada nasofaring yang baru didapat atau persisten. Kelompok dengan sepsis berulang memiliki angka mortalitas yang lebih besar daripada pasien dengan episode tunggal sepsis. ${ }^{30}$

Beberapa infeksi berat disebabkan bakteri yang berkapsul seperti pneumokokus (Streptococcus pneumoniae). Kurang lebih 50-90\% kàsus yang dilaporkan dengan $60 \%$ mortalitas terjadi pada infeksi kuman ini. Dua puluh lima persen selebihnya disebabkan Haemophilus influenzae type $B$, meningococcus dan Streptococcus group A. ${ }^{24}$
Mikroorganisme lain adalah Capnocytophaga canimorsus (dulu dikenal dengan $D F-2$ ) yang pernah dilaporkan menyebabkan sepsis fulminan setelah gigitan anjing. Organisme yang lebih jarang mencakup Streptococcus group B. Enterokokus $s p$, bacteroides $s p$, Salmonella $s p$ dan Bartonella, Plesiomonas shigelloides, Eubacterium plautii, dan Pseudomonas pseudomallei. ${ }^{31}$

Genotipe hemoglobin mempunyai peran dalam prevalens ulkus tungkai. Pada pasien thalassemia terdapat prevalens yang tinggi walaupun kurang jika dibandingkan dengan sickle cell disease. Anemia juga merupakan faktor risiko terjadinya ulkus tungkai. Kadar hemoglobin kurang dari 6 g/dl dihubungkan dengan 43,2 kasus setiap 100 pasien per tahun; sedangkan kadar hemoglobin lebih dari $6 \mathrm{~g} / \mathrm{dl}$, didapatkan pada setiap 100 pasien per tahun. Infeksi sekunder sering terjadi dan seringkali disebabkan oleh Staphylococcus aureus dan Pseudomonas aeruginosa. ${ }^{32}$

Suatu studi menunjukkan bahwa desferal merupakan faktor predisposisi terhadap infeksi S.aureus karena komponen protein yang terdapat didalamnya digunakan untuk pertumbuhan bakteri. Pada suatu studi didapatkan pasien thalassemia beta yang mendapat terapi kelasi desferoxamine, $S$. aureus dan coagulase-negative staphylococci merupakan 17 dari 19 penyebab komplikasi infeksi. Desferoxamine juga meningkatkan kerentanan terhadap infeksi Klebsiella, Salmonella dan $Y$. enterocolitica. ${ }^{33}$

Pasien yang ditransfusi juga mengalami risiko terjadinya sepsis pasca transfusi akibat kontaminasi darah oleh flora kulit atau bakteremia tingkat rendah pada saat plebotomi. Bakteri berproliferasi selama penyimpanan. Contohnya, Yersinia enterocolitica berkembang terutama pada suhu dingin dengan lingkungan yang kaya besi. Setelah transfusi $50-70 \mathrm{ml}$ darah pasien menderita demam, menggigil dan muntah. Selanjutnya hipotensi, syok dan DIC dapat terjadi dalam waktu 90 menit pasien transfusi. Gejala yang hebat terjadi berhubungan dengan endotoksin yang diproduksi organisme Gram negatif. Gambaran klinik yang lebih ringan terdapat pada mikroorganisme Gram positif. Yersinia merupakan penyebab kebanyakan reaksi tersebut, tetapi organisme lain seperti Pseudomonas putida dan P.fluoresence dapat mengkontaminasi eritrosit. Jika dicurigai terjadi reaksi sepsis, infus harus dihentikan dan segera dilanjutkan penanganan suportif serta perlindungan antibiotik 
spektrum luas. Pemeriksaan mikrobiologi termasuk pewarnaan Gram dan kultur darah harus dilakukan. Penemuan bakteri menunjang diagnosis, tetapi sepsis dapat terjadi walaupun basil pewarnaan Gram negatif. ${ }^{13}$

Pasien yang mengalami splenektomi berisiko mendapat infeksi berat dari bakteri yang tidak berkapsul. Pasien yang mengalami splenektomi akan rentan terhadap infeksi yang disebut dengan overwhelming post splenectomy infection (OPSI) yang disebabkan terutama oleh S.pneumoniae (terdapat pada 50-90\% kasus), Meningokokus, Haemophilus influenzae type $B$ (pada $25 \%$ kasus). ${ }^{31}$

Limpa berperan dalam menyaring darah dan berperan pada respons antibodi awal, sehingga sepsis (dengan atau tanpa meningitis) dapat berkembang dengan sangat cepat dan menyebabkan kematian dalam 12-24 jam setelah onset. ${ }^{34}$

Streptococcus pneumoniae merupakan mikroorganisme patogen utama pada sepsis pasca splenektomi $(50-90 \%$ kasus). Streptococcus pneumoniae juga berperan pada 60\% infeksi yang fatal. ${ }^{12}$ Haemophilus influenzae menempati urutan kedua dan berperan pada 32\% infeksi yang fatal; sedangkan Neisseria meningitidis merupakan penyebab penting meningitis pada sepsis. Tiga patogen ini berperan pada $73 \%$ dan semua infeksi.

Laporan dan the Cooperative Study of Sickle Cell Disease menunjukkan dari 694 pasien terdapat 17 pasien yang mengalami infeksi S.pneumoniae berulang. ${ }^{26}$ Asplenia, baik fungsional atau anatomi pasca splenektomi merupakan risiko terjadinya infeksi pneumokokus. Risiko terbesar terdapat pada pasien thalassemia dalam beberapa tahun pertama pasca splenektomi. Untuk menurunkan risiko sepsis pasca splenektomi, imunisasi terhadap pneumokokus dan H.influenzae harus diberikan 1 bulan sebelum operasi. ${ }^{11,30}$

Laporan lain menyebutkan insidens bakteremia tidak meningkat pada pasien thalassemia. Lebih jauh lagi, tidak seperti perjalanan penyakit anak dengan sickle cell anemia, pasien-pasien ini jarang berkembang menjadi septikemi yang mengancam jiwa. Hal ini mungkin sebagai akibat fungsi limpa yang relatif utuh selama bayi dan anak pada pasien-pasien tersebut. Profilaksis penisilin terhadap pasien-pasien ini mungkin tidak diperlukan. ${ }^{35}$

Vaksin polisakarida pneumokokus direkomendasikan pada anak 2 tahun atau lebih dengan asplenia yang risiko terhadap infeksi pneumokokus. Revaksinasi direkomendasikan setelah 3-5 tahun pada pasien di bawah 10 tahun dan setelah 5 tahun untuk pasien yang lebih tua atau yang mempunyai faktor risiko infeksi pneumokokus berat seperti pasien dengan asplenia. ${ }^{28,30,36}$

Infeksi yersinia dan mucormycosis adalah penyulit yang berhubungan dengan pemberian deferoxamine. ${ }^{5}$ Peningkatan fungsi hati selama pemberian deferipone, suatu obat penggati desferoksamin, yang terjadi lebih sering pada pasien yang terinfeksi hepatitis. ${ }^{37}$

\section{Infeksi Parasit}

Risiko transmisi malaria pada populasi terjadi sekitar 1:4 juta. $^{13}$ Berdasarkan distribusi thalassemia di Mediterania, Haldane berpendapat pada varian gen tertentu terdapat resistensi terhadap malaria. Proteksi yang didapat adalah proteksi terhadap kematian dan malaria berat, terhadap uncomplicated malaria dan yang paling kecil adalah terkena infeksi malaria. ${ }^{38}$ Mekanisme proteksi ini masih belum jelas. Diduga tekanan oksigen yang rendah menurunkan invasi dan pertumbuhan parasit dalam eritrosit. Terdapat bukti-bukti yang terbatas bahwa perubahan respons imun pada individu dengan varian gen globin mungkin berperan penting pada resistensi terhadap malaria. ${ }^{13,38}$

Terdapat bukti bahwa pada eritrosit yang mengandung $\mathrm{HbF}$ tinggi terdapat proteksi terhadap malaria P.falciparum dengan mekanisme perlambatan pertumbuhan parasit dan sifat tetramer yang super stabil yang dimiliki HbF. ${ }^{9}$ Didapatkan hubungan yang jelas antara thalassemia alfa dengan insidens dan prevalens malaria. Suatu penelitian kasus kelola di Papua Nuigini menunjukkan bahwa pada thalassemia alfa terdapat efek protektif yang sangat bermakna terhadap komplikasi yang serius malaria P.falciparum. ${ }^{39}$ Eritrosit normal dan eritosit pada pasien thalassemia rentan terhadap invasi P.falciparum tetapi multiplikasi parasit diturunkan secara bermakna pada populasi eritrosit pasien thalassemia. ${ }^{40}$

\section{Lain-lain}

Penyebab infeksi lain yang dapat ditularkan melalui transfusi adalah babesia, bartonella, virus Epstein-Barr dan toksoplasma. Tidak terdapat kasus baru sifilis yang ditularkan lewat transfusi akhir-akhir ini. Human herpes virus 8 , merupakan virus yang dihubungkan dengan varkoma kaposi, ditunjukkan dapat ditularkan secara invitro. ${ }^{13}$ 


\section{Kesimpulan}

- Kasus thalassemia mempunyai kerentanan terhadap infeksi baik akibat faktor penyakitnya sendiri maupun akibat pengobatan.

- Berbagai mikroorganisme terutama virus dan bakteri dapat menyebabkan infeksi pada pasien thalassemia.

- Dari golongan virus, virus Hepatitis merupakan penyebab penyakit infeksi yang tersering, sedangkan dari golongan bakteri, sepsis pasca splenektomi akibat $S$.pneumoniae merupakan penyebab tersering dan seringkali bersifat fatal.

- Monitor terhadap thalassemia harus dilakukan seumur hidup mengingat banyaknya penyulit yang mungkin timbul.

\section{Daftar pustaka}

1. Wahidiyat I. Thalassemia dan permasalahannya di Indonesia. Disampaikan pada Kongres Nasional Ilmu Kesehatan Anak XI, Jakarta, 4-7 Juli, 1999.

2. Bowman WP. Thalassemia. Dalam: Dambro MR. penyunting. Griffith's 5-Minute Clinical Consult;. Edisi ke-3. Philadelphia: Lippincott Williams \& Wilkins, 2001. h. 1058-9.

3. Matondang CS, Notoatmojo H. Mekanisme imun penyakit infeksi. Dalam: Akib AP,Matondang CS, penyunting. Buku Ajar Alergi dan Imunologi. Jakarta: PP IDAI 1996. h. 95-9.

4. Lynch AM, Kapila R. Overwhelming postsplenectomy infection. Infect Dis Clin North Am 1996; 10:693-707.

5. Ahluwalia J, Datta U, Marwaha RK, Sehgal S. Immune functions in splenectomized thalassaemic children. Indian J Pediatr 2000; 12:871-6. (abstrak)

6. Weinberg ED. Cellular acquisition of iron and the ironwithholding defense againts mikrobial and neoplastic invasion. Dalam: Lauffer RB, penyunting. Iron and Human disease. Florida: CRC Press,1992. h.179-208.

7. Brock JH. Iron and the immune system. Dalam: Lauffer $\mathrm{RB}$, penyunting. Iron and Human disease. Florida; CRC Press, 1992. h. 161-78.

8. Feigin RD,Matson DO. The compromised host. Dalam : Feigin RD, Cherry JD, penyunting. Textbook of Pediatric diseases . Edisi ke-2. Philadelphia: WB Saunders Company 1987. h. 1015.

9. Menitove JE. Transfusion-transmitted infections : Update. Semin Hematol 1996; 33:290-301.

10. Davis AB, Porter JB. Long-term outcome of continous 24-hour deferoxamine infusion via indwelling intravenous catheters in high risk - -thalassemia. Blood 2000; 95:1229-36.

11. Wahidiyat I. Penelitian thassemia di Jakarta. Tesis . Jakarta: Bagian Ilmu Kesehatan Anak FKUI, 1979.
12. Giardini C,Lucarelli C . Bonne marrow transplantation for beta-thalassemia. Hematol Oncol Clin North Am 1999; 13:1059-63.

13. Menitove JE. Blood transfusion. Dalam: Goldman L, Bennet JC, penyunting. Cecil Textbook of Medicine. Edisi ke-21., Philadelphia: W.B. Saunders Company ,2000. h. 906-11.

14. Perrine SP. Pathophysiology: basic mechanisms of hemoglobin synthesis. Dalam: Rake! RE, Bope ET, penyunting. Rake!: Conn's Current Therapy 2001. Edisi ke-53. Philadelphia: W.B. Saunders Company, 2001. h. 370-4.

15. Aach RD,Yomtovian RA, Hack M. Neonatal and pediatrics post transfussion hepatitis C: a look back and a look forward. Pediatrics 2000; 105:836-42.

16. Jonas MM . Treatment of Chronic Hepatitis Cm Pediatric Patients. Clin Liver Dis 1999; 3:855-65.

17. Pratti D, Zanella A, Farma E, Mattei CD, Bosoni F, Zappa M, et al. A multicenter prospective study on the risk of acquiring liver disease in anti-hepatitis $\mathrm{C}$ virus negative patients affected from homozygous -3 -thalassemia. Blood 1998; 92:3460-4.

18. Fishman LN, Jonas MM,Lavine JE. Update on viral hepatitis in children. Pediatr Clin North Am1996; 43:5774.

19. Strasser SI, McDonald GB. Hepatitis viruses and hematopoietic cell transplantation: a guide to patient and donor management. Blood 1999; 93:1127-36.

20. Hasan MF, Marsh F, Posner G,Bellevue R, Dosik H, Suatengco $\mathrm{R}$ et al. Chronic hepatitis $\mathrm{C}$ in patients with sickle cell disease. Am J Gastroenterol 1996; 9:924-6.

21. Gonzalez-Peralta RP. Hepatitis C virus infection in pediatric patients. Clin Liver Dis 1997; 1:691-705.

22. Krawczynski K,Aggarwal R,Kamili S. Hepatitis E. Infect Dis Chin North Am 2000; 3:669-87.

23. Prati D, Zanella A, BosoniP, Rebulla P, Farma B, Mattei $\mathrm{C}$, et a!. The incidence and natural course of transfusionassociated GB Virus C/Hepatitis G virus infection in a cohort of thalassemic patients. Blood 1998; 91:774-7.

24. Bonis PAL .U virus. J Am Soc Nephrol .1999; 10:182832.

25. Prati D, Lin YH, De Mattei C, Liu JK, Farma E, Ramaswamy L, et al. A prospective study on TI Virus infection in transfusion-dependent patients with betaThalassemia. Blood 1999; 93:1502-5.

26. Naides SJ. Rheumatic manifestations of parvovirus B19 infection. Rheum Dis Chin North Am 1998; 24:375401.

27. Mustafa MM, McClain KL. Diverse hematologic effect of Parvovirus B 19 infection. Ped Clin North Am 1996; 43:810-21.

28. Alger LS. Toxoplasmosis and Parvovirus B19 . Infect Dis Clin North Am 1997; 11:55-75

29. Embury SH. Sickle cell anemia and associated hemoglobinopathies. Dalam: Goldman L,Bennet JC, penyunting. Cecil Textbook of Medicine. Edisi ke-21. Philadelphia: W.B. SaundersCompany, 2000. h. 894-905.

30. Peter G, Klein JO. Pneumococcal Vaccine . Pediatr Rev 1996; 17:335-41.

31. Brigden ML, Patullo AL. Prevention and management 
of overwhelming post splenectomy Infection: an update. Crit care med 1999; 27:836-42.

32. Eckman JR. Leg ulcers in sickle cell disease. Hematol Oncol Gin North Am 1996; 10:1333-44

33. Sebulsky MT, Hohnstein D, Hunter MD, Heinrich DE. Identification and characterization of a membrane permease involved in iron-hydroxamate transport in Staphylococcus aureus. J Bacteriol, 2000; 182:4394-400.

34. French J, Camitta BM. The Spleen. Dalam: Berhman RE, Kliegman RM, Arvin AM, penyunting. Textbook of Pediatrics. Edisi ke-15. Philadelphia: W.B. Saunders Company, 1996. h. 1439-40.

35. Rogers ZR, Buchanan GR. Bacteremia in children with sickle hemoglobin $\mathrm{C}$ disease and sickle beta+ -thalassemia: Is prophylactic penicillin necessary?. J Pediatr 1995; 127:348-54.
36. Rubin LG . Pneumococcal vaccine. Pediatr Clin North Am 2000; 47:269-85.

37. Diav-Citrin 0, Koren G. Oral iron chelation with deferiprone. Pediatr Clin North Am 1997; 44:235-47.

38. Hill AUS. Human genetic and infection. Dalam: Mandell GL, Bennet JE, Dolin R, penyunting. Principles and practice of infectious diseases. Edisi ke-5. Philadelphia: Churchill Livingstone, 2000. h. 39-40.

39. Weatherall D, Clegg J, Kwiatkowski D .The role of genomics in studying genetic susceptibility to infectious disease. Genome Research 1997; 7:967-973.

40. Pattanapanyasat K, Yongvanitchit K, Tongtawe P, Tachavanich K, Wanachiwanawin W, Fucharoen S et al. Impairment of Plasmodiumfalciparum growth in thalassemic red blood cells: further evidence by using biotin labeling and flow cytometry. Blood 1999; 93:3116-9 